\title{
EFFICIENCY SCORES ANALYSIS OF COAL MINES USING IRS, DRS AND CROSS EFFICIENCY MODELS
}

\author{
Dr. G. Thirupati Reddy ${ }^{1 *}$ \\ *l Principal \& Professor, Dept of Mechanical Engineering, Sree Visvesvaraya Institute of Tech. \& Science, \\ ahabubnagar, Telengana State, India E-mail: gtr_osho@yahoo.co.in
}

*Corresponding Author: -

E-mail:gtr_osho@yahoo.co.in

\begin{abstract}
: -
Economic growth world over is driven by energy, whether in the form of finite resources such as coal, oil and gas or in renewable forms such as hydroelectric, wind, solar and bio-mass or its converted form, electricity(power). Increased energy consumption (especially of electricity) is inevitable with higher GDP growth. Coal was created by the fossilised remains of plants and has high carbon content.

DEA is a multi-factor productivity analysis model for measuring the relative efficiency of a homogenous set of coal mines (DMU's). For every inefficient coal mine, DEA identifies a set of corresponding efficient coal mines that can be utilized as benchmarks for improvement of performance and productivity.

Benchmarking and ranking of coal mines based on efficiency scores using advanced DEA models like, Increasing Returns to Scale (IRS), Decreasing Returns to Scale (DRS), Cross Efficiency (CE) Models.
\end{abstract}

Keywords: - Efficiency, ranking, peer group, target production 


\section{INTRODUCTION}

The analysis carried out using TORA and DEA Software's. The analysis also carried out of OC Mines using some of the advanced

DEA Models as follows:

1.Increasing Returns Scale (IRS) Model

2.Decreasing Returns Scale (IRS) Model

3. Cross Efficiency ( CE ) Model

\section{Increasing Returns Scale (IRS) and Decreasing Returns Scale (DRS) Models}

Returns to scale refers to a technical property of production that examines changes in output subsequent to a proportional change in all inputs (where all inputs increase by a constant). The output increases by that same proportional change with input then there are constant returns to scale (CRTS), sometimes referred to simply as returns to scale. If output increases by less than that proportional change, there are decreasing returns to scale (DRS). If output increases by more than that proportion, there are increasing returns to scale (IRS).

Example: Where all inputs increase by a factor of 2, new values for output should be: Twice the previous output given a constant return to scale (CRTS) less than twice the previous output given a decreased return to scale (DRS) more than twice previous output given an increased return to scale (IRS).

\section{Cross Efficiency (CE) Model}

Cross efficiency in DEA allows for effective discrimination between niche performers and good overall performers. Cross efficiency [48] score of a DMU represents how well the unit is performing with respect to the optimal weights of another DMU. A DMU that achieves high cross efficiency scores is considered to be a good overall perform to improve the discrimination power of DEA, Sexton et al (1986) first introduces the concept of a cross-efficiency measure in DEA. The basic idea is to use DEA in a peerappraisal instead of a self-appraisal, which is calculated by the CRS (constant returns to scale) model. Peer evaluation is done by constituting a cross efficiency matrix of efficiency value given to each DMUs. This technique can also identify 'overall' efficient and 'false positive' DMUs, and it selects appropriate targets for poorly performing DMUs to learn as a benchmark.

\section{Methodology}

Cross Efficiency Models: Aggressive and Benevolent Approaches Aggressive Model

Benevolent Model

$$
\begin{aligned}
& \min \sum_{k=1}^{s}\left(v_{k} \sum_{i \neq p} y_{k i}\right) \\
& \text { s.t } \sum_{j=1}^{m}\left(u_{j} \sum_{i \neq p} x_{j i}\right)=1 \\
& \sum_{k=1}^{s} v_{k} y_{k i}-\sum_{j=1}^{m} u_{j} x_{j i} \leq 0, \quad \forall i \neq p \\
& \sum_{k=1}^{s} v_{k} y_{k p}-\theta_{p} \sum_{j=1}^{m} u_{j} x_{j p}=0 \\
& v_{k}, u_{j} \geq 0 \quad \forall k, j \\
& \max \sum_{k=1}^{s}\left(v_{k} \sum_{i \neq p} y_{k i}\right) \\
& \text { s.t } \sum_{j=1}^{m}\left(u_{j} \sum_{i \neq p} x_{j i}\right)=1 \\
& \sum_{k=1}^{s} v_{k} y_{k i}-\sum_{j=1}^{m} u_{j} x_{j i} \leq 0, \quad \forall i \neq p \\
& \sum_{k=1}^{s} v_{k} y_{k p}-\theta_{p} \sum_{j=1}^{m} u_{j} x_{j p}=0 \\
& v_{k}, u_{j} \geq 0 \quad \forall k, j
\end{aligned}
$$

\section{Data collection and Analysis}

For the empirical application we worked with data on a survey of 15 Open Cast (OC) mines of Singareni Colleries Company Limited (SCCL). For our analysis, we have chosen four input variables namely,

1. Wage Cost ( In Lakhs rupees per year),

2. Store Cost (In Lakhs rupees per year), 
3. OBR Cost (In Lakhs rupees per year),

4. Other cost (In Lakhs rupees per year) and one output variable namely

5. Production (in Lakh Tonnes per year),

Table1: Normalized Data for Open-Cast mines

\begin{tabular}{|c|c|c|c|c|c|}
\hline \multicolumn{7}{|c|}{ Normalized data of OC mines } \\
\hline Mines(DMU) & $\begin{array}{c}\text { Wage } \\
\text { Cost }\end{array}$ & $\begin{array}{c}\text { Store } \\
\text { Cost }\end{array}$ & $\begin{array}{r}\text { OBR } \\
\text { Cost }\end{array}$ & $\begin{array}{c}\text { Other } \\
\text { Cost }\end{array}$ & Production \\
\hline OCM1 & 1.4159 & 1.3481 & 1.6260 & 1.5881 & 1.4980 \\
\hline OCM2 & 0.4178 & 0.2750 & 1.1271 & 0.6606 & 1.0283 \\
\hline OCM3 & 0.8347 & 0.3747 & 0.2395 & 0.2439 & 0.4547 \\
\hline OCM4 & 0.2877 & 0.0429 & 0.0886 & 1.4318 & 0.9398 \\
\hline OCM5 & 2.2116 & 2.7843 & 1.0544 & 1.9245 & 1.6182 \\
\hline OCM6 & 0.1794 & 0.3421 & 0.5946 & 0.3132 & 0.6900 \\
\hline OCM7 & 0.0900 & 0.0640 & 0.1193 & 0.0033 & 0.1348 \\
\hline OCM8 & 0.8788 & 0.6435 & 2.3050 & 0.6806 & 1.2584 \\
\hline OCM9 & 0.4472 & 0.3099 & 1.5266 & 0.3449 & 0.7523 \\
\hline OCM10 & 0.3140 & 0.1812 & 0.5095 & 0.1531 & 0.4167 \\
\hline OCM11 & 0.2761 & 0.0975 & 0.4884 & 0.2727 & 0.4347 \\
\hline OCM12 & 0.8668 & 0.4730 & 1.9179 & 0.5059 & 1.3427 \\
\hline OCM13 & 2.5188 & 3.8545 & 1.5713 & 2.2644 & 2.1494 \\
\hline OCM14 & 1.7423 & 1.7183 & 0.7791 & 0.7015 & 0.8720 \\
\hline OCM15 & 2.5188 & 2.4909 & 1.0527 & 3.9112 & 1.4102 \\
\hline
\end{tabular}

\section{Increasing Returns Scale (IRS) Model}

Returns to scale refers to a technical property of production that examines changes in output subsequent to a proportional change in all inputs (where all inputs increase by a constant). If output increases by more than that proportion, there are increasing returns to scale (IRS) which is under DEA IRS and DRS Models. The analysis carried out using Input-oriented CCR data and DEA software and results are shown in table 2.

Table2: Efficiency, Shadow values, Peer group and Peer count values after solving Input-oriented IRS Model

\begin{tabular}{|c|c|c|c|c|}
\hline DMU & Efficiency & shadow Values & Peer Group & $\begin{array}{c}\text { Peer } \\
\text { Count }\end{array}$ \\
\hline OCM1 & $55.10 \%$ & $0.577,0.086,6.651$ & OCM4,OCM6,OCM7 & 0 \\
\hline OCM2 & $100 \%$ & 1 & OCM2 & 5 \\
\hline OCM3 & $100 \%$ & 1 & OCM3 & 5 \\
\hline OCM4 & $100 \%$ & 1 & OCM4 & 6 \\
\hline OCM5 & $67.80 \%$ & $1.234,0.694,3.001$ & OCM3,OCM4,OCM7 & 0 \\
\hline OCM6 & $100 \%$ & 1 & OCM6 & 4 \\
\hline OCM7 & $100 \%$ & 1 & OCM7 & 10 \\
\hline OCM8 & $71.40 \%$ & $0.656,0.129,3.669$ & OCM2,OCM6,OCM7 & 0 \\
\hline OCM9 & $85.70 \%$ & $0.431,0.012,2.235$ & OCM2,OCM6,OCM7 & 0 \\
\hline OCM10 & $83.40 \%$ & $0.042,1.653,0.346$ & OCM2,OCM7,OCM11 & 0 \\
\hline OCM11 & $100 \%$ & 1 & OCM11 & 3 \\
\hline OCM12 & $96.40 \%$ & $0.153,4.39,1.365$ & OCM2,OCM7,OCM11 & 0 \\
\hline OCM13 & $68.20 \%$ & $1.094,0.878,6.134$ & OCM3,OCM4,OCM7 & 0 \\
\hline OCM14 & $64.30 \%$ & $1.093,0.124,1.913$ & OCM3,OCM4,OCM7 & 0 \\
\hline OCM15 & $39.70 \%$ & $0.723,0.958,1.34$ & OCM3,OCM4,OCM7 & 0 \\
\hline
\end{tabular}




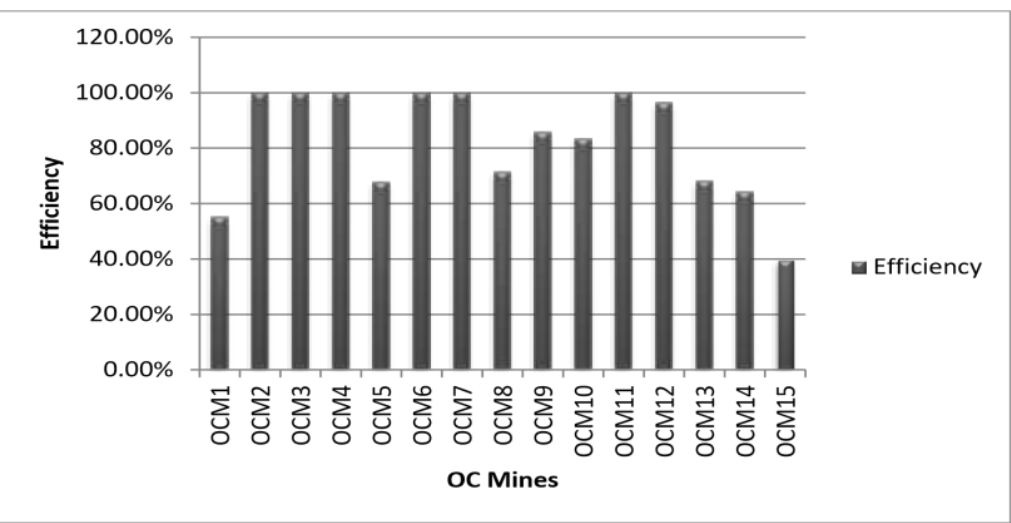

Fig 1: OC Mines Vs Efficiency score for Input-oriented IRS Model

Table 3: Improvements in Inputs and Output of OC Mines after solving Input - oriented IRS model

\begin{tabular}{|c|c|c|c|c|c|}
\hline & Wage Cost & Store Cost & OBR Cost & Other Cost & Production \\
\hline DMU & $\begin{array}{c}\text { Actual to } \\
\text { Target }\end{array}$ & $\begin{array}{c}\text { Actual to } \\
\text { Target }\end{array}$ & $\begin{array}{c}\text { Actual to } \\
\text { Target }\end{array}$ & $\begin{array}{c}\text { Actual to } \\
\text { Target }\end{array}$ & $\begin{array}{c}\text { Actual to } \\
\text { Target }\end{array}$ \\
\hline OCM1 & $\begin{array}{c}1.416 \text { to } \\
0.78 \\
\end{array}$ & $\begin{array}{c}1.348 \text { to } \\
0.48 \\
\end{array}$ & $\begin{array}{c}1.626 \text { to } \\
0.896 \\
\end{array}$ & $\begin{array}{c}1.588 \text { to } \\
0.875 \\
\end{array}$ & $\begin{array}{c}1.498 \text { to } \\
1.498 \\
\end{array}$ \\
\hline OCM2 & $\begin{array}{c}0.418 \text { to } \\
0.418 \\
\end{array}$ & $\begin{array}{c}0.275 \text { to } \\
0.275\end{array}$ & $\begin{array}{c}1.127 \text { to } \\
1.127 \\
\end{array}$ & $\begin{array}{c}0.661 \text { to } \\
0.661 \\
\end{array}$ & $\begin{array}{c}1.028 \text { to } \\
1.028 \\
\end{array}$ \\
\hline OCM3 & $\begin{array}{c}0.835 \text { to } \\
0.835 \\
\end{array}$ & $\begin{array}{c}0.375 \text { to } \\
0.375 \\
\end{array}$ & 0.24 to 0.24 & $\begin{array}{c}0.244 \text { to } \\
0.244 \\
\end{array}$ & $\begin{array}{c}0.455 \text { to } \\
0.455\end{array}$ \\
\hline OCM4 & $\begin{array}{c}0.288 \text { to } \\
0.288 \\
\end{array}$ & $\begin{array}{c}0.043 \text { to } \\
0.043 \\
\end{array}$ & $\begin{array}{c}0.089 \text { to } \\
0.089\end{array}$ & $\begin{array}{c}1.432 \text { to } \\
1.432 \\
\end{array}$ & 0.94 to 0.94 \\
\hline OCM5 & 2.212 to 1.5 & $\begin{array}{c}2.784 \text { to } \\
0.684\end{array}$ & $\begin{array}{c}1.054 \text { to } \\
0.715\end{array}$ & $\begin{array}{c}1.924 \text { to } \\
1.305\end{array}$ & $\begin{array}{c}1.618 \text { to } \\
1.618 \\
\end{array}$ \\
\hline OCM6 & $\begin{array}{c}0.179 \text { to } \\
0.179\end{array}$ & $\begin{array}{c}0.342 \text { to } \\
0.342\end{array}$ & $\begin{array}{c}0.595 \text { to } \\
0.595\end{array}$ & $\begin{array}{c}0.313 \text { to } \\
0.313\end{array}$ & 0.69 to 0.69 \\
\hline OCM7 & 0.09 to 0.09 & $\begin{array}{c}0.064 \text { to } \\
0.064 \\
\end{array}$ & $\begin{array}{c}0.119 \text { to } \\
0.119 \\
\end{array}$ & $\begin{array}{c}0.003 \text { to } \\
0.003 \\
\end{array}$ & $\begin{array}{c}0.135 \text { to } \\
0.135 \\
\end{array}$ \\
\hline OCM8 & $\begin{array}{c}0.879 \text { to } \\
0.627 \\
\end{array}$ & $\begin{array}{c}0.644 \text { to } \\
0.459 \\
\end{array}$ & $\begin{array}{c}2.305 \text { to } \\
1.254\end{array}$ & $\begin{array}{c}0.681 \text { to } \\
0.486\end{array}$ & $\begin{array}{c}1.258 \text { to } \\
1.258\end{array}$ \\
\hline OCM9 & $\begin{array}{c}0.447 \text { to } \\
0.383 \\
\end{array}$ & $\begin{array}{c}0.31 \text { to } \\
0.266\end{array}$ & $\begin{array}{c}1.527 \text { to } \\
0.759\end{array}$ & $\begin{array}{c}0.345 \text { to } \\
0.296\end{array}$ & $\begin{array}{c}0.752 \text { to } \\
0.752\end{array}$ \\
\hline OCM10 & $\begin{array}{c}0.314 \text { to } \\
0.262 \\
\end{array}$ & $\begin{array}{c}0.181 \text { to } \\
0.151 \\
\end{array}$ & $\begin{array}{c}0.509 \text { to } \\
0.414 \\
\end{array}$ & $\begin{array}{c}0.153 \text { to } \\
0.128 \\
\end{array}$ & $\begin{array}{c}0.417 \text { to } \\
0.417 \\
\end{array}$ \\
\hline OCM11 & $\begin{array}{c}0.276 \text { to } \\
0.276 \\
\end{array}$ & $\begin{array}{c}0.098 \text { to } \\
0.098 \\
\end{array}$ & $\begin{array}{c}0.488 \text { to } \\
0.488 \\
\end{array}$ & $\begin{array}{c}0.273 \text { to } \\
0.273 \\
\end{array}$ & $\begin{array}{c}0.435 \text { to } \\
0.435 \\
\end{array}$ \\
\hline OCM12 & $\begin{array}{c}0.867 \text { to } \\
0.836 \\
\end{array}$ & $\begin{array}{c}0.473 \text { to } \\
0.456 \\
\end{array}$ & $\begin{array}{c}1.918 \text { to } \\
1.363 \\
\end{array}$ & $\begin{array}{c}0.506 \text { to } \\
0.488 \\
\end{array}$ & $\begin{array}{c}1.343 \text { to } \\
1.343 \\
\end{array}$ \\
\hline OCM13 & $\begin{array}{c}2.519 \text { to } \\
1.718 \\
\end{array}$ & $\begin{array}{c}3.854 \text { to } \\
0.84\end{array}$ & $\begin{array}{c}1.571 \text { to } \\
1.072 \\
\end{array}$ & $\begin{array}{c}2.264 \text { to } \\
1.544 \\
\end{array}$ & $\begin{array}{c}2.149 \text { to } \\
2.149 \\
\end{array}$ \\
\hline OCM14 & $\begin{array}{c}1.742 \text { to } \\
1.121 \\
\end{array}$ & $\begin{array}{c}1.718 \text { to } \\
0.537\end{array}$ & $\begin{array}{c}0.779 \text { to } \\
0.501\end{array}$ & $\begin{array}{c}0.702 \text { to } \\
0.451\end{array}$ & $\begin{array}{c}0.872 \text { to } \\
0.872 \\
\end{array}$ \\
\hline OCM15 & 2.519 to 1 & $\begin{array}{c}2.491 \text { to } \\
0.398\end{array}$ & $\begin{array}{c}1.053 \text { to } \\
0.418\end{array}$ & $\begin{array}{c}3.911 \text { to } \\
1.553\end{array}$ & 1.41 to 1.41 \\
\hline
\end{tabular}




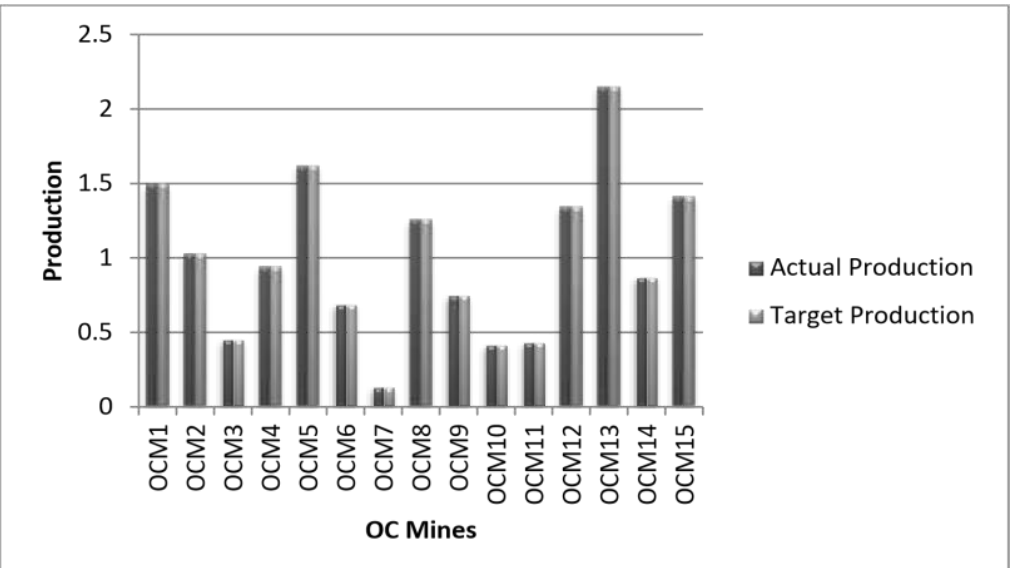

Fig 2: Actual Production Vs Target Production for Input-oriented IRS Model 2. Decreasing Returns Scale (DRS) Model

The analysis carried out using DEA software and results are shown in table 4.

Table 4: Efficiency, Peer group and Peer count values after solving Output-oriented DRS Model

\begin{tabular}{|r|c|c|c|}
\hline DMU & Efficiency & Peer Group & $\begin{array}{c}\text { Peer } \\
\text { Count }\end{array}$ \\
\hline OCM1 & $98.60 \%$ & OCM4,OCM12,OCM13 & 0 \\
\hline OCM2 & $100 \%$ & OCM2 & 3 \\
\hline OCM3 & $100 \%$ & OCM3 & 1 \\
\hline OCM4 & $100 \%$ & OCM4 & 5 \\
\hline OCM5 & $95 \%$ & OCM4,OCM6,OCM13 & 0 \\
\hline OCM6 & $100 \%$ & OCM6 & 5 \\
\hline OCM7 & $100 \%$ & OCM7 & 3 \\
\hline OCM8 & $93.30 \%$ & OCM12,OCM13 & 0 \\
\hline OCM9 & $90.50 \%$ & OCM2,OCM6,OCM7,OCM12 & 0 \\
\hline OCM10 & $94 \%$ & OCM2,OCM6,OCM7,OCM12 & 0 \\
\hline OCM11 & $100 \%$ & OCM11 & 1 \\
\hline OCM12 & $100 \%$ & OCM12 & 6 \\
\hline OCM13 & $100 \%$ & OCM13 & 6 \\
\hline OCM14 & $89.40 \%$ & OCM4,OCM6,OCM13 & 0 \\
\hline OCM15 & $82.10 \%$ & OCM4,OCM12,OCM13 & 0 \\
\hline
\end{tabular}

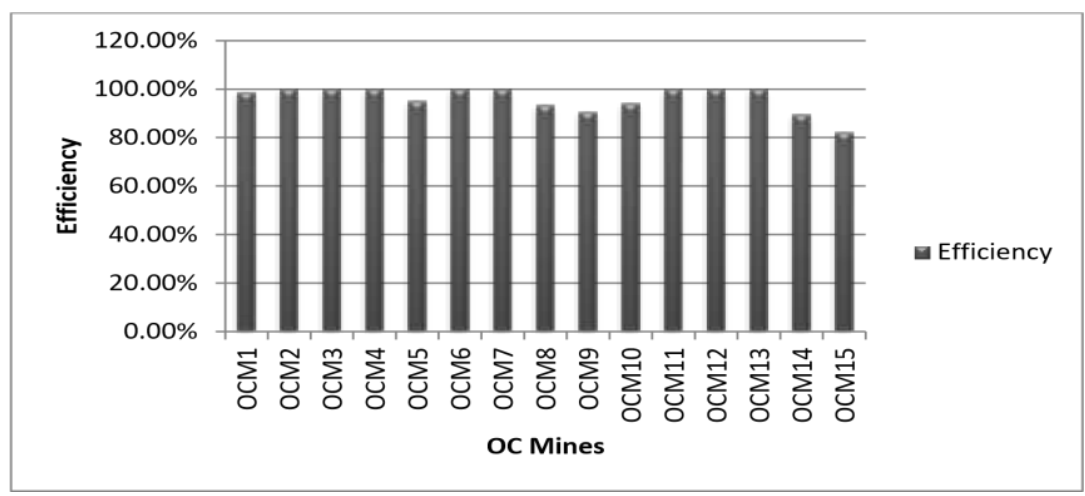

Fig 3: OC Mines Vs Efficiency score for Output-oriented DRS Model

The target production of in-efficient mines is increased drastically by adjusting slack variable in concerned input value and results are shown in table 5. 
Table 5: Improvements in Inputs and Output of OC Mines after solving Output - oriented DRS model

\begin{tabular}{|c|c|c|c|c|c|}
\hline & $\begin{array}{l}\text { Wage } \\
\text { Cost }\end{array}$ & $\begin{array}{c}\text { Store } \\
\text { Cost }\end{array}$ & $\begin{array}{c}\text { OBR } \\
\text { Cost }\end{array}$ & $\begin{array}{c}\text { Other } \\
\text { Cost }\end{array}$ & Production \\
\hline DMU & $\begin{array}{c}\text { Actual to } \\
\text { Target }\end{array}$ & $\begin{array}{c}\text { Actual } \\
\text { to } \\
\text { Target }\end{array}$ & $\begin{array}{c}\text { Actual } \\
\text { to } \\
\text { Target }\end{array}$ & $\begin{array}{c}\text { Actual } \\
\text { to } \\
\text { Target }\end{array}$ & $\begin{array}{c}\text { Actual to } \\
\text { Target }\end{array}$ \\
\hline OCM1 & $\begin{array}{c}1.416 \text { to } \\
1.254\end{array}$ & $\begin{array}{c}1.348 \text { to } \\
1.348 \\
\end{array}$ & $\begin{array}{c}1.626 \text { to } \\
1.626\end{array}$ & $\begin{array}{c}1.588 \text { to } \\
1.085 \\
\end{array}$ & $\begin{array}{c}1.498 \text { to } \\
1.519\end{array}$ \\
\hline OCM2 & $\begin{array}{c}0.418 \text { to } \\
0.418\end{array}$ & $\begin{array}{c}0.275 \text { to } \\
0.275 \\
\end{array}$ & $\begin{array}{c}1.127 \text { to } \\
1.127 \\
\end{array}$ & $\begin{array}{c}0.661 \text { to } \\
0.661 \\
\end{array}$ & $\begin{array}{c}1.028 \text { to } \\
1.028\end{array}$ \\
\hline OCM3 & $\begin{array}{c}0.835 \text { to } \\
0.835\end{array}$ & $\begin{array}{c}0.375 \text { to } \\
0.375\end{array}$ & $\begin{array}{c}0.24 \text { to } \\
0.24\end{array}$ & $\begin{array}{c}0.244 \text { to } \\
0.244 \\
\end{array}$ & $\begin{array}{c}0.455 \text { to } \\
0.455\end{array}$ \\
\hline OCM4 & $\begin{array}{c}0.288 \text { to } \\
0.288\end{array}$ & $\begin{array}{c}0.043 \text { to } \\
0.043\end{array}$ & $\begin{array}{c}0.089 \text { to } \\
0.089\end{array}$ & $\begin{array}{c}1.432 \text { to } \\
1.432 \\
\end{array}$ & 0.94 to 0.94 \\
\hline OCM5 & $\begin{array}{c}2.212 \text { to } \\
1.71 \\
\end{array}$ & $\begin{array}{c}2.784 \text { to } \\
2.49\end{array}$ & $\begin{array}{c}1.054 \text { to } \\
1.054\end{array}$ & $\begin{array}{c}1.924 \text { to } \\
1.924 \\
\end{array}$ & $\begin{array}{c}1.618 \text { to } \\
1.704 \\
\end{array}$ \\
\hline OCM6 & $\begin{array}{c}0.179 \text { to } \\
0.179\end{array}$ & $\begin{array}{c}0.342 \text { to } \\
0.342\end{array}$ & $\begin{array}{c}0.595 \text { to } \\
0.595\end{array}$ & $\begin{array}{c}0.313 \text { to } \\
0.313\end{array}$ & 0.69 to 0.69 \\
\hline OCM7 & $\begin{array}{c}0.09 \text { to } \\
0.09\end{array}$ & $\begin{array}{c}0.064 \text { to } \\
0.064\end{array}$ & $\begin{array}{c}0.119 \text { to } \\
0.119\end{array}$ & $\begin{array}{c}0.003 \text { to } \\
0.003 \\
\end{array}$ & $\begin{array}{c}0.135 \text { to } \\
0.135 \\
\end{array}$ \\
\hline OCM8 & $\begin{array}{c}0.879 \text { to } \\
0.879 \\
\end{array}$ & $\begin{array}{c}0.644 \text { to } \\
0.498 \\
\end{array}$ & $\begin{array}{c}2.305 \text { to } \\
1.915 \\
\end{array}$ & $\begin{array}{c}0.681 \text { to } \\
0.519\end{array}$ & $\begin{array}{c}1.258 \text { to } \\
1.349 \\
\end{array}$ \\
\hline OCM9 & $\begin{array}{c}0.447 \text { to } \\
0.447 \\
\end{array}$ & $\begin{array}{c}0.31 \text { to } \\
0.31 \\
\end{array}$ & $\begin{array}{c}1.527 \text { to } \\
1.038 \\
\end{array}$ & $\begin{array}{c}0.345 \text { to } \\
0.345 \\
\end{array}$ & $\begin{array}{c}0.752 \text { to } \\
0.831 \\
\end{array}$ \\
\hline OCM10 & $\begin{array}{c}0.314 \text { to } \\
0.236 \\
\end{array}$ & $\begin{array}{c}0.181 \text { to } \\
0.181\end{array}$ & $\begin{array}{c}0.509 \text { to } \\
0.509\end{array}$ & $\begin{array}{c}0.153 \text { to } \\
0.153\end{array}$ & $\begin{array}{c}0.417 \text { to } \\
0.443\end{array}$ \\
\hline OCM11 & $\begin{array}{c}0.276 \text { to } \\
0.276\end{array}$ & $\begin{array}{c}0.098 \text { to } \\
0.098\end{array}$ & $\begin{array}{c}0.488 \text { to } \\
0.488\end{array}$ & $\begin{array}{c}0.273 \text { to } \\
0.273\end{array}$ & $\begin{array}{c}0.435 \text { to } \\
0.435\end{array}$ \\
\hline OCM12 & $\begin{array}{c}0.867 \text { to } \\
0.867 \\
\end{array}$ & $\begin{array}{c}0.473 \text { to } \\
0.473\end{array}$ & $\begin{array}{c}1.918 \text { to } \\
1.918 \\
\end{array}$ & $\begin{array}{c}0.506 \text { to } \\
0.506\end{array}$ & $\begin{array}{c}1.343 \text { to } \\
1.343\end{array}$ \\
\hline OCM13 & $\begin{array}{c}2.519 \text { to } \\
2.519\end{array}$ & $\begin{array}{c}3.854 \text { to } \\
3.854\end{array}$ & $\begin{array}{c}1.571 \text { to } \\
1.571\end{array}$ & $\begin{array}{c}2.264 \text { to } \\
2.264\end{array}$ & $\begin{array}{c}2.149 \text { to } \\
2.149\end{array}$ \\
\hline OCM14 & $\begin{array}{c}1.742 \text { to } \\
0.634\end{array}$ & $\begin{array}{c}1.718 \text { to } \\
1.02 \\
\end{array}$ & $\begin{array}{c}0.779 \text { to } \\
0.779\end{array}$ & $\begin{array}{c}0.702 \text { to } \\
0.702\end{array}$ & $\begin{array}{c}0.872 \text { to } \\
0.975\end{array}$ \\
\hline OCM15 & $\begin{array}{c}2.519 \text { to } \\
1.723\end{array}$ & $\begin{array}{c}2.491 \text { to } \\
2.491\end{array}$ & $\begin{array}{c}1.053 \text { to } \\
1.053\end{array}$ & $\begin{array}{c}3.911 \text { to } \\
1.959\end{array}$ & $\begin{array}{c}1.41 \text { to } \\
1.719\end{array}$ \\
\hline
\end{tabular}

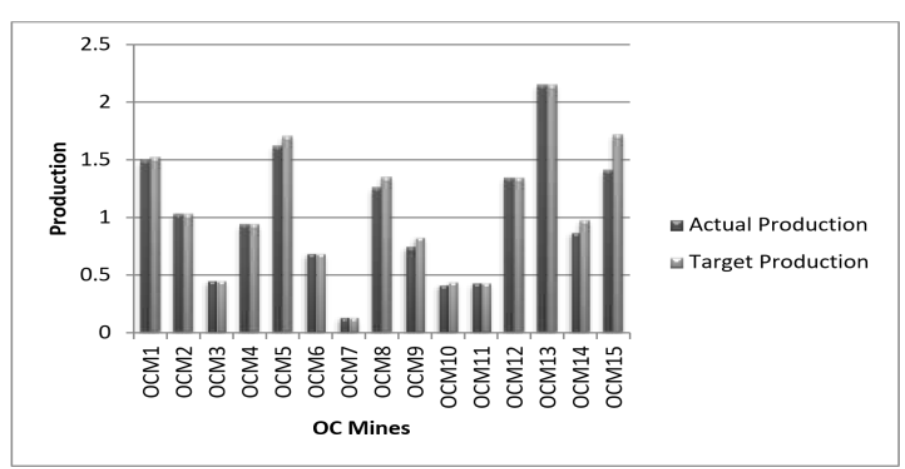

Fig 4: Actual Production Vs Target Production for Output-oriented DRS Model 


\section{Cross Efficiency (CE) Model}

This problem solved using algorithm 7 and DEAP software, the results are shown in table 6.

Table 6: Results produced after solving Cross Efficiency model for 10 OC Mines

\begin{tabular}{|c|c|c|c|c|c|c|c|c|c|c|c|}
\hline & $\begin{array}{c}\text { Efficien } \\
\text { cy }\end{array}$ & $\begin{array}{c}\text { OCM } \\
1\end{array}$ & $\begin{array}{c}\mathrm{OCM} \\
2\end{array}$ & $\begin{array}{c}\mathrm{OCM} \\
3\end{array}$ & $\begin{array}{c}\mathrm{OCM} \\
4\end{array}$ & $\begin{array}{c}\mathrm{OCM} \\
5\end{array}$ & $\begin{array}{c}\text { OCM } \\
6\end{array}$ & $\begin{array}{c}\text { OCM } \\
7\end{array}$ & $\begin{array}{c}\text { OCM } \\
8\end{array}$ & $\begin{array}{c}\text { OCM } \\
9\end{array}$ & $\begin{array}{c}\text { OCM1 } \\
0\end{array}$ \\
\hline OCM1 & 55.09 & 55.09 & 74.48 & 63.5 & 100 & 56.55 & 100 & 100 & 50.47 & 49.16 & 68.11 \\
\hline OCM2 & 100 & 47.17 & 100 & 45.58 & 100 & 31.89 & 100 & 100 & 67.75 & 76.07 & 80.55 \\
\hline OCM3 & 100 & 54.67 & 64.07 & 100 & 100 & 67.82 & 83.8 & 100 & 43.43 & 40.7 & 64.04 \\
\hline OCM4 & 100 & 55.09 & 74.48 & 63.5 & 100 & 56.55 & 100 & 100 & 50.47 & 49.16 & 68.11 \\
\hline OCM5 & 67.82 & 54.67 & 64.07 & 100 & 100 & 67.82 & 83.8 & 100 & 43.43 & 40.7 & 64.04 \\
\hline OCM6 & 100 & 55.09 & 74.48 & 63.5 & 100 & 56.55 & 100 & 100 & 50.47 & 49.16 & 68.11 \\
\hline OCM7 & 100 & 47.17 & 100 & 45.58 & 100 & 31.89 & 100 & 100 & 67.75 & 76.07 & 80.55 \\
\hline OCM8 & 71.4 & 43.03 & 100 & 38.96 & 78.19 & 28.07 & 100 & 100 & 71.4 & 85.69 & 80.05 \\
\hline OCM9 & 85.69 & 43.03 & 100 & 38.96 & 78.19 & 28.07 & 100 & 100 & 71.4 & 85.69 & 80.05 \\
\hline $\begin{array}{c}\text { OCM1 } \\
0\end{array}$ & 83.42 & 40.44 & 100 & 43.41 & 82.58 & 24.95 & 84.43 & 100 & 70.48 & 85.52 & 83.42 \\
\hline
\end{tabular}

\section{Conclusions}

From table 2 OCM7 referred 10 times as a peer count is most efficient unit in all aspects and used as a referring mine for other mines to improve their productivity based on this IRS analysis. OCM15 shown very poor performance is $39.70 \%$. If output increases by less than that proportional change, there are decreasing returns to scale (DRS) which is described in 3.6 under DEA IRS and DRS Models. The analysis carried out using DEA software and results are shown in table 4. Lot of improvement in efficiency scores shown in DRS model solved using Output- oriented CCR model. OCM12 and OCM13 got maximum peer count of 6 that means these two mines referred maximum number of times for other inefficient mines for improving their performance. Cross efficiency in DEA allows for effective discrimination between niche performers and good overall performers. Cross efficiency score of a DMU represents how well the unit is performing with respect to the optimal weights of another DMU.

Here we have solved only 10 OC Mines due to space problem existed in width wise of efficiencies for representing in rows wise and column wise for effective comparison with efficiencies of other in-efficient mines

\section{References}

[1] Andersen, P., \& Petersen, N.C. (1993). A Procedure for ranking efficient units in data envelopment analysis. Management Science, 39 (10), 1261-1264.

[2] Boussofiane, A.,Dyson, R.G.,\& Thanassoulis, E.(1991). Applied dataenvelopment analysis. European Journal of Operational Research, 52, 1-15.

[3] Charnes, A., Cooper, W. W., \& Rhodes, E. (1978). Measuring the efficiency of decision making units. European Journal of Operational Research, 2, 429-444.

[4] Charnes, A., Cooper, W. W., Lewin, A. Y., \& Seiford, L. M. (Eds). (1994). Data envelopment analysis: Theory, methodology, and applications. Boston: Kluwer.

[5] Talluri, S., Huq, F., \& Pinney, W. E. (1997). Application of data envelopment analysis for cell performance evaluation and process improvement in cellular manufacturing. International Journal of Production Research, 35(8), $2157-2170$.

[6] Thompson, R. G., Dharmapala, P. S., \& Thrall, R. M. (1995). Linked-cone DEA profit ratios and technical efficiency with application to Illinois coal mines. International Journal of Production Economics, 39, 99-115.

[7] Charnes, A. and W.W. Cooper, 1961, Management Models and Industrial Applications of Linear Programming, 2 vols. with A. Charnes (New York: John Wiley and Sons, Inc.).

[8] Cooper, W.W., Seiford, L.M. and Tone, K., 2000, Data Envelopment Analysis: A Comprehensive Text with Models, Applications, References and DEA-Solver Software, Kluwer Academic Publishers, Boston.

[9] Banker, R.D. and R.C. Morey, 1986b, The use of categorical variables in data envelopment analysis, Management Science 32, No. 12, 1613-1627.

[10] Srinivas Talluri, Data Envelopment Analysis: Models and Extensions, 2000, the journal of Production/Operations management.

[11] www.dea-analysis.com

[12] www.deaos.com 